NEWS

\title{
Bookshelf: A Selection of Recent Publications from UCL Institute of Archaeology
}

\author{
Jennifer French and Marion Cutting
}

\section{A Selection of Recent Publications from UCL Institute of Archaeology.}

The Institute of Archaeology produces two well-established series of books: a General Series (series editor Ruth Whitehouse) and the Critical Cultural Heritage sub-series (series editor Beverley Butler). These have been published since December 2015 by Routledge, a branch of Taylor \& Francis.

In addition, the Institute is planning to enter into a new partnership with BAR Publishing to publish final revised PhD theses. It is hoped through this to establish a substantial series which will promote the Institute's outstanding postgraduate research programme across the theory and practice of archaeology, conservation, and heritage.

One book in the General Series has been published by Routledge since last January. Two books are nearly ready for publication, another one is with referees, and eight manuscript proposals have been approved (subject to positive refereeing).

\section{General Series}

Tim Denham. 2018. Tracing Early Agriculture in the Highlands of New Guinea. Plot, Mound and Ditch

Historical narratives chart how people created forms of agriculture in the highlands and how these practices were transformed

UCL Institute of Archaeology, GB

Corresponding author: Jennifer French (jennifer.french@ucl.ac.uk)

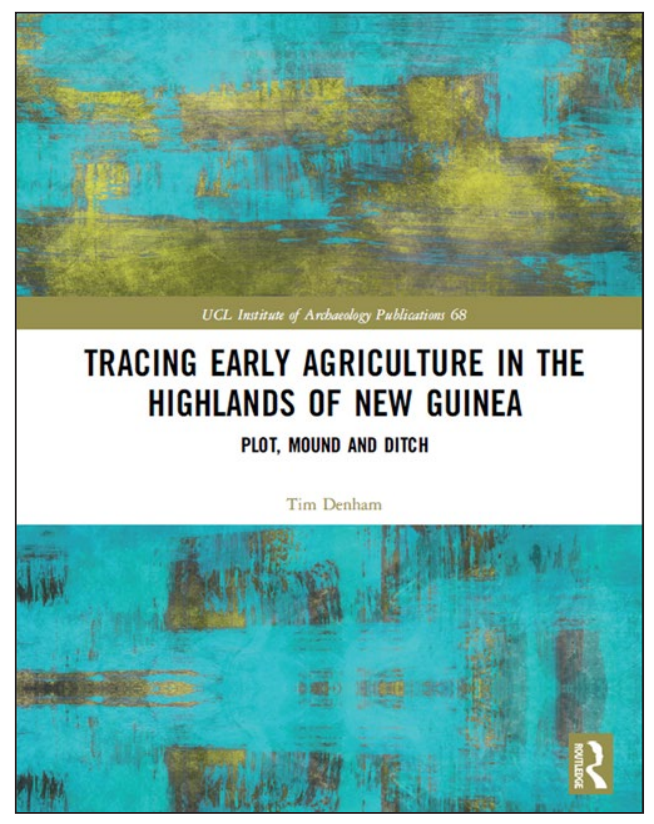

through time. New Guinea is established as a region of early agricultural development and plant domestication, and a contingent, practice-based interpretation of early agriculture is presented that has broader application to other regions of the world. Early agriculture in the highlands is charted by an exposition of the practices of plant exploitation and cultivation in a way that will be relevant to archaeologists studying the transitions from foraging to farming, and researchers and students across a range of disciplines (including agronomists, 
anthropologists, geneticists, geographers, and linguists) working in the Indo-Pacific region.

Many other books have been published by Institute staff between 2017 and 2018 . Some of these are featured below.

\section{Glaire D. Anderson, Corisande} Fenwick and Mariam Rosser-Owen (Eds). 2017. The Aghlabids and their Neighbors: Art and Material Culture in Ninth-Century North Africa. Leiden, Brill. Handbook of Oriental Studies 122

Aghlabid rule in North Africa has been neglected by scholars, despite the canonical status of its monuments and artworks in early Islamic art history. The Aghlabids and their Neighbors focuses new attention on this key dynasty and its material culture. The essays in this handbook, produced by an international group of specialists in history, archaeology, art and architectural history, and numismatics, illuminate the Aghlabid dynasty's interactions with neighbouring states in the Islamic West and its rivals and allies elsewhere, providing a state of the question on early medieval North Africa and revealing the centrality of the dynasty and the region to global economic and political networks.

\section{Jane Briscoe, Barbara Martin, David} Martin and Christopher Whittick. 2018. How Houses Evolved: Houses in the Eastern High Weald of Sussex 1350-1750. Spoilheap Publications, Monograph 19

A synthetic analysis of the plan, form, and design features of the houses of eastern Sussex. Based on 50 years of research, this volume compares and contrasts houses through time, across different settlement types, and throughout the entire social spectrum, with the aim of understanding the evolution of the house as a home in this region.
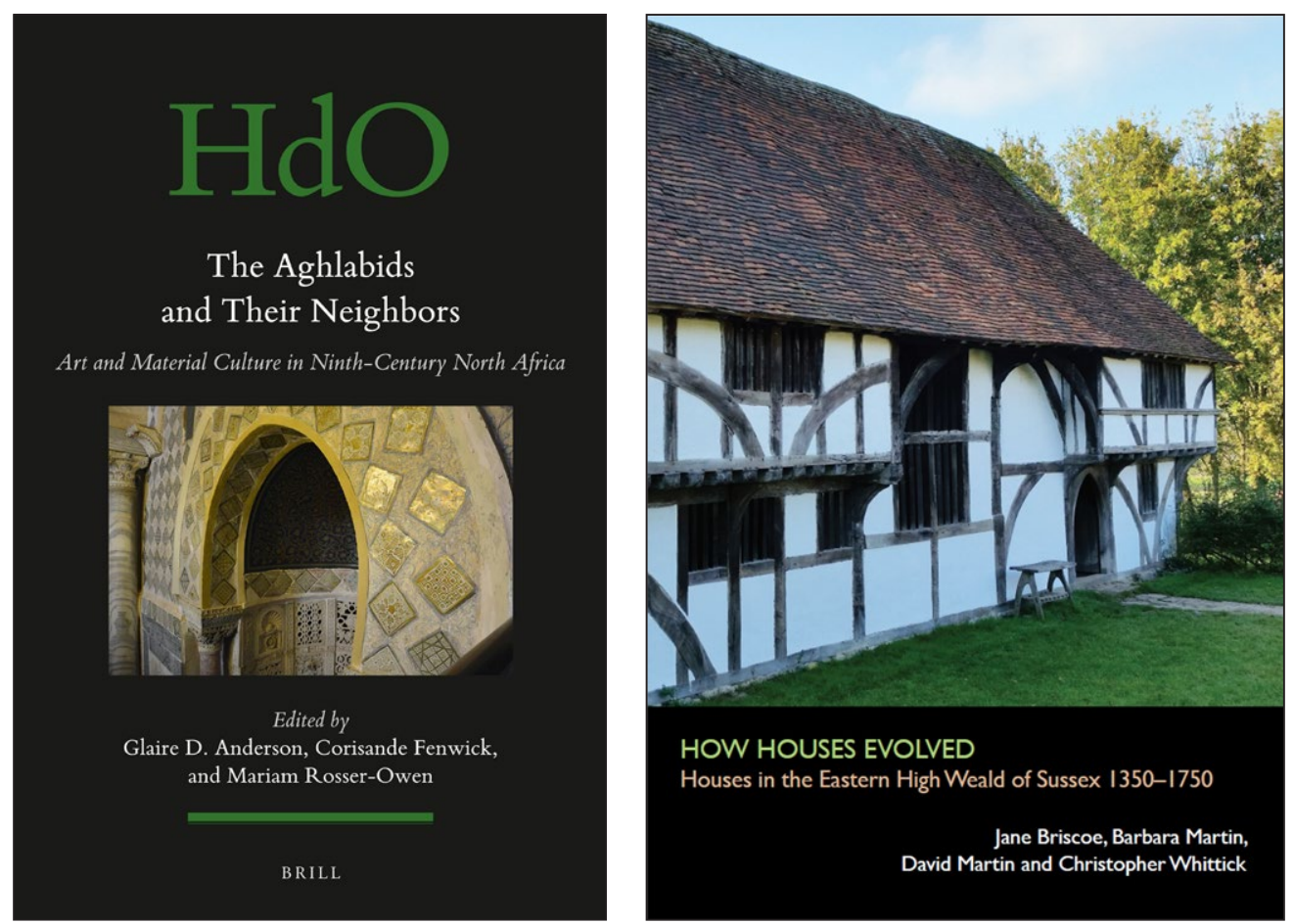
Kerstin Hofmann, Reinhard Bernbeck and Ulrike Sommer (Eds). 2017. Between Memory Sites and Memory Networks. New Archaeological and Historical Perspectives. Berlin, Topoi. Berlin Studies of the Ancient World 45 This book takes stock of earlier work on memory in the fields of history and the social sciences. Our collection also takes a new look at how past and present social groups have memorialised events and rendered them durable through materialisations. Contributors ask how processes and incidents perceived as negative and disruptive are nonetheless constitutive of group identities. Papers also contrast the monumentalising treatment given to singular events imbued with a hegemonic meaning to more localised and diverse, memory places and networks. The temporal scope of the volume reaches from the late Neolithic to the recent past, resulting in a longterm and multi-focal perspective that demonstrates how the perception of past events changes, acquires new layers, and is moulded by different groups at different points in time.

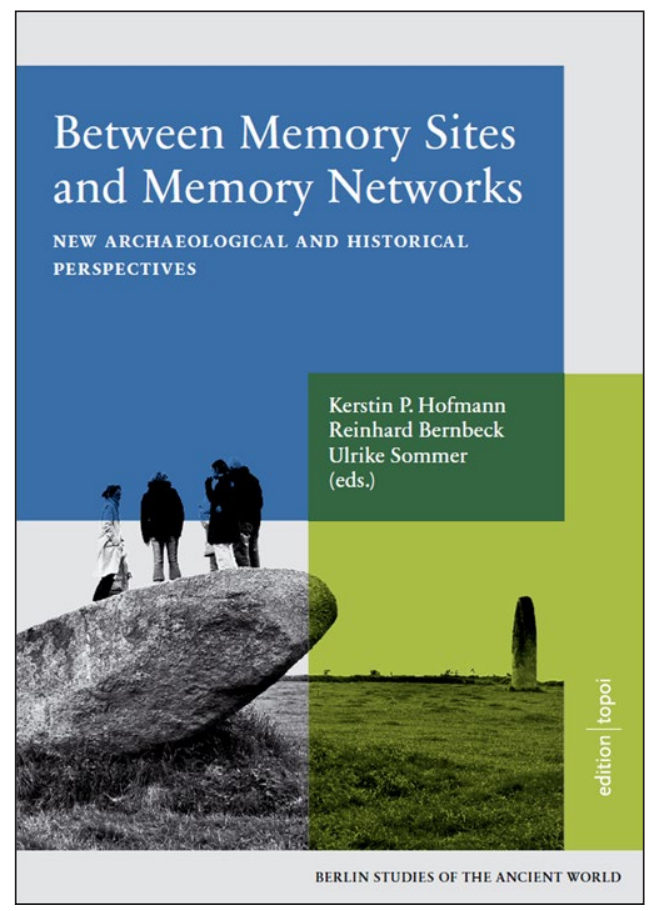

Jill Hohenstein and Theano

Moussouri. 2018. Museum Learning:

Theory and Research as Tools for Enhancing Practice. London, Routledge

Museum Learning attempts to make sense of multiple learning theories whilst focusing on a set of core learning topics in museums. Importantly, learning is considered not just as a cognitive characteristic, as some perspectives propose, but also as affective, taking into consideration interests, attitudes, and emotions; and as a social practice situated in cultural contexts. This book draws attention to the development of theory and its practical applications in museum situations such as aquariums, zoos, botanical gardens and historical re-enactment sites, among others. This volume will be of interest to museum studies students, practitioners and researchers working in informal learning contexts, and will help them to reflect on what it means to learn in museums and create more effective environments for learning.

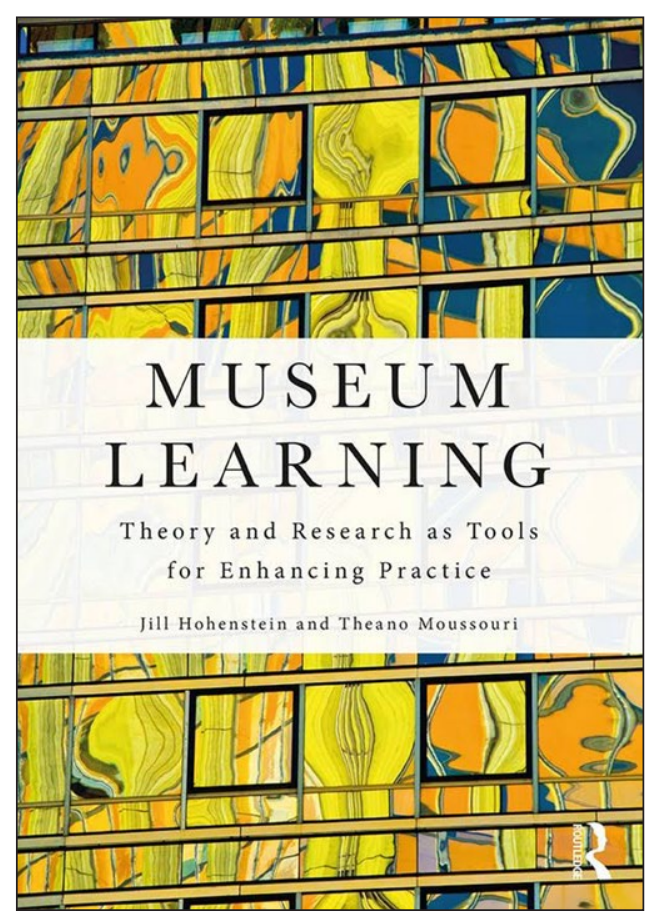




\section{Gianluca Miniaci, Juan Carlos} Moreno García, Stephen Quirke and Andréas Stauder (Eds). 2018. The Arts of Making in Ancient Egypt. Voices, Images, and Objects of Material Producers 2000-1550 $B C$. Sidestone Press

During the past decades, the 'imaginative' figure of ancient Egyptian material producers has moved from 'workers' to 'artisans' and, most recently, to 'artists'. In a search for a fuller understanding of the pragmatics of material production in past societies, and moving away from a series of modern preconceptions, this volume aims: to analyse the mechanisms of material production in Egypt during the Middle Bronze Age (2000-1550 BC); to approach the profile of ancient Egyptian craftsmen through their own words, images and artefacts; and to trace possible modes of circulation of ideas among craftsmen in material production. This book provides an innovative analysis of the conditions of ancient Egyptian craftsmanship in the light of the

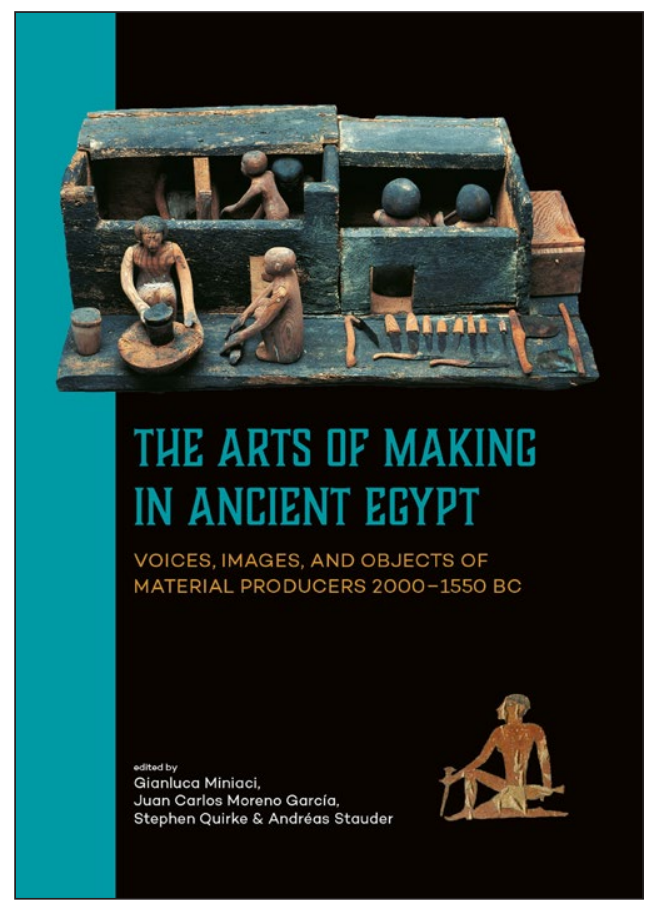

archaeology of production, linguistic analysis, visual representation and ethnographic research. The studies in the volume address the mechanisms of ancient production in Middle Bronze Age Egypt, the circulation of ideas among craftsmen, and the profiles of the people involved, based on the material traces, including depictions and writings, the ancient craftsmen themselves left and produced.

Andrew Margetts. 2018. WEALDBAERA: Excavations at Wickhurst Green, Broadbridge Heath and the Landscape of the West Central Weald. Spoilheap Publications, Monograph 18

Extensive excavations, carried out between 2007 and 2015, uncovered important remains dating from the Mesolithic to post-medieval periods at Wickhurst Green, Broadbridge Heath in West Sussex, providing the first real opportunity to archaeologically explore the Weald on a landscape scale. The site was home to hunter-gatherers, Iron

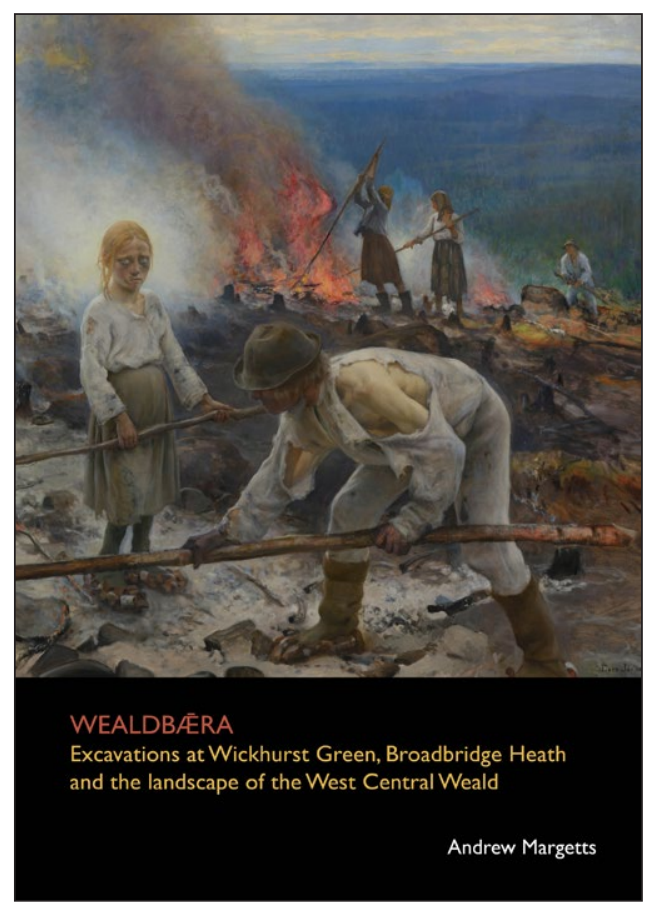


Age pastoralists, funerary monuments, Roman agriculture, and industry. The work aims to set the results of this developerfunded site within its broader landscape context.

Mike Parker Pearson, Mark

Brennand, Jacqui Mulville and Helen Smith. 2018. Cille Pheadair. A Norse Farmstead and Pictish Burial Cairn in South Uist. Oxford, Oxbow Publications

Cille Pheadair is one of more than 20 Viking Age and Late Norse settlements discovered on the island of South Uist in the Outer Hebrides (Western Isles), off the west coast of Scotland. Its unusually wellpreserved stratigraphic sequence of nine phases of occupation, including five longhouses and many smaller buildings, provides a remarkable insight into daily life on a Norse farmstead during two centuries of near-continuous occupation c. AD 1000-1200. Cille Pheadair's status as an

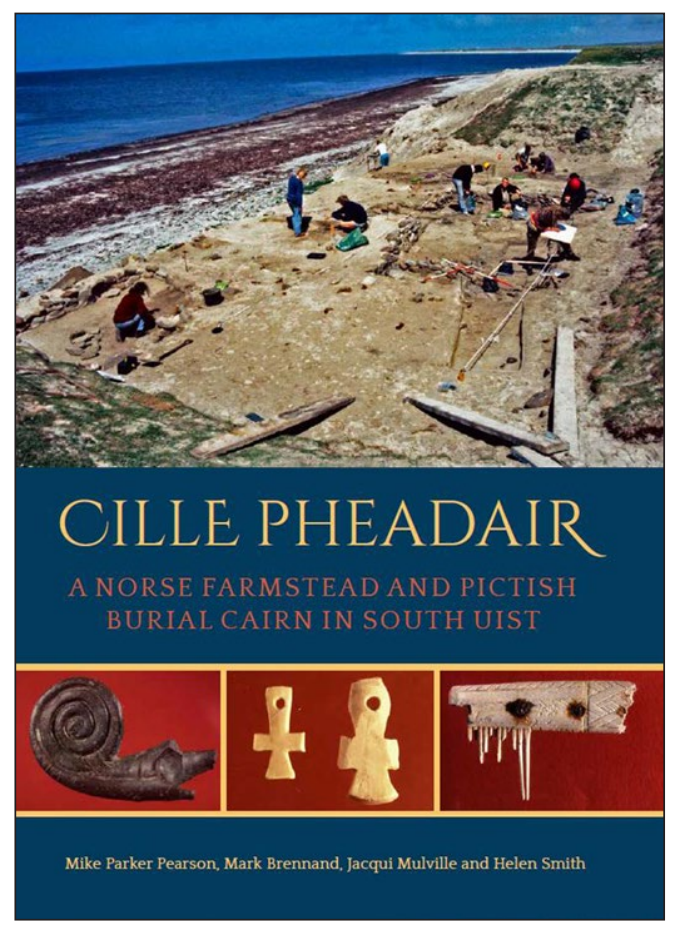

ordinary, if wealthy, farmstead can be contrasted with the much larger and longerlived high-status settlement at Bornais to the north. The two sites together provide a fascinating insight into similarities and differences within the settlement hierarchy of the time that makes a significant contribution to our understanding of the Viking world.

Matt Pope, Clive Gamble and John McNabb (Eds). 2017. Crossing the Human Threshold: Dynamic Transformation and Persistent Places during the Middle Pleistocene. London, Routledge

When was the human threshold crossed? What is the evidence for evolving humans and their emerging humanity? This volume explores in a global overview the archaeology of the Middle Pleistocene, 800,000 to 130,000 years ago, when evidence for innovative cultural behaviour appeared.

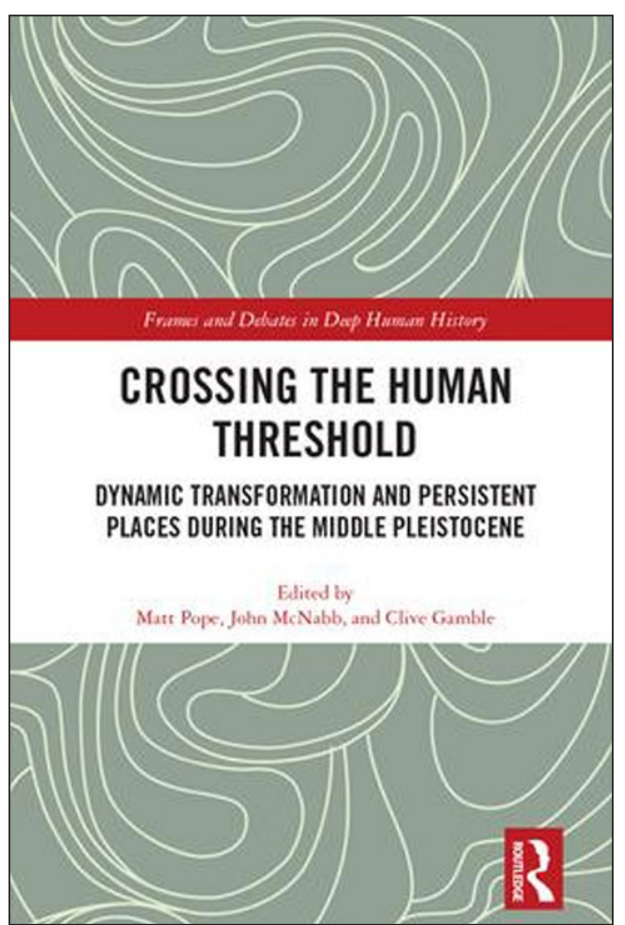


The evidence shows that the threshold was crossed slowly, by a variety of human ancestors, and was not confined to one part of the Old World.

Lucy Sibun and Paola Ponce. 2018. In Life and Death: Archaeological Excavations at the Queen's Chapel of the Savoy, London. Spoilheap Publications, Monograph 17

Excavations carried out within the burial ground of the Queen's Chapel of the Savoy, City of Westminster, London, in 2011 provided a unique opportunity to examine the archaeological and historical development of this fascinating location. This was the site of Henry VII's $16^{\text {th }}$-century hospital for the poor, which was converted into a military hospital in the $17^{\text {th }}$ century, became the barracks and prison of the Foot Guards in the $18^{\text {th }}$ century, and was redeveloped for civilian use in the $19^{\text {th }}$ century. The associated burial ground was utilised throughout the life of the buildings and beyond, until the final burial in 1854.

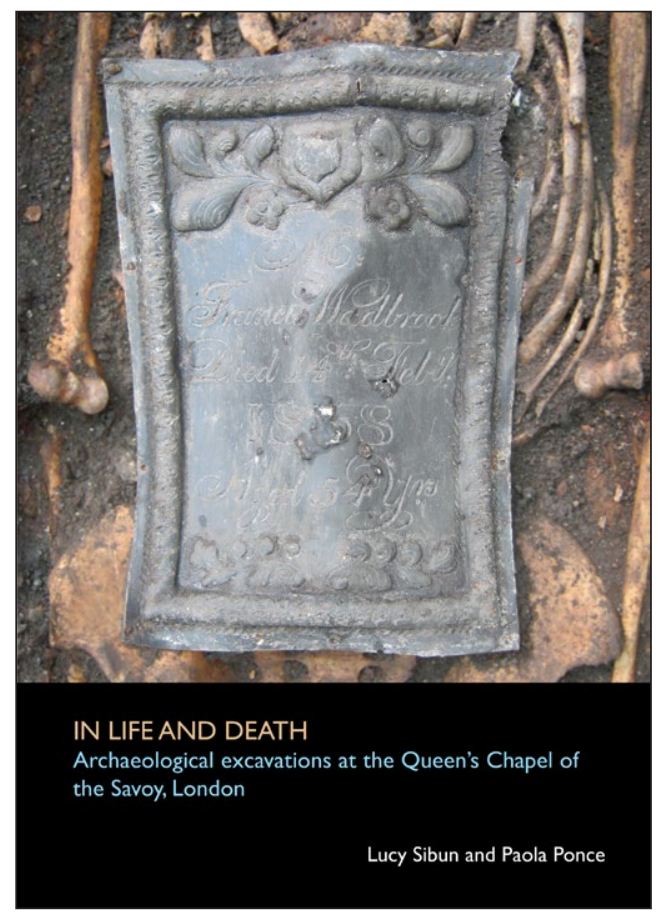

Stephen Shennan. 2018. The First Farmers of Europe. An Evolutionary Perspective. Cambridge University Press, World Archaeology Series

Knowledge of the origin and spread of farming has been revolutionised in recent years by the application of new scientific techniques, especially the analysis of ancient DNA from human genomes. This book presents the latest research on the spread of farming by archaeologists, geneticists and other archaeological scientists, showing that it resulted from a population expansion from present-day Turkey. Using ideas from the disciplines of human behavioural ecology and cultural evolution, this book explains how this process took place. The expansion was not the result of 'population pressure' but of the opportunities for increased fertility by colonising new regions that farming offered. The knowledge and resources for the farming 'niche' were passed on from parents to their children. However, demographic patterns associated with the spread of farming resulted in population booms and busts, not continuous expansion.

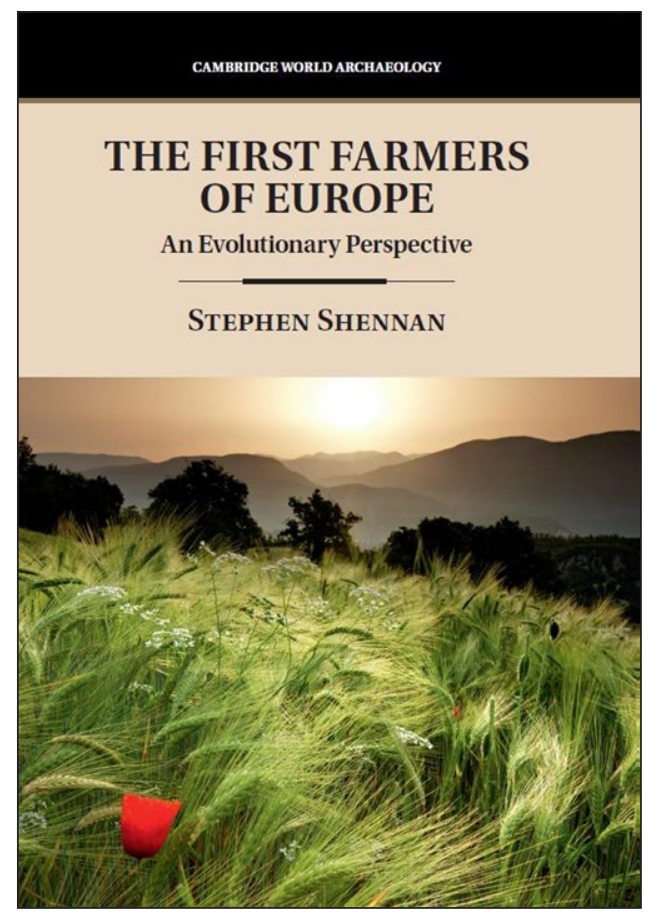

